\title{
IMPLEMENTASI MANAJEMEN PROGRAM GERAKAN LITERASI MADRASAH DI MAN 1 LAMONGAN
}

\author{
Saida Rifda Barokah \\ Universitas Islam Negeri Sunan Ampel Surabaya | Adityarifda@gmail.com \\ Yensika Yosi Bentari \\ Universitas Islam Negeri Sunan Ampel Surabaya |
}

\begin{abstract}
Abstrak: Penelitian ini bertujuan untuk mendeskripsikan implementasi menejemen program Gerakan Literasi Madrasah, menjelaskan tahap-tahap pelaksanaan program Gerakan Literasi Madrasah, menjelaskan kelebihan dan kekurangan dari program Gerakan Literasi Madrasah di MAN 1 Lamongan. Teknik pengumpulan data yang digunakan adalah wawancara, observasi, dan dokumentasi. Keabsahan data menggunakan triangulasi sumber dan teknik. Teknik analisis data menggunakan teknik analisis Miles dan Huberman meliputi reduksi data, menyajikan data, dan menarik kesimpulan. Hasil pembahasan implementasi menejemn program Gerakan Literasi Madrasah di MAN 1 Lamongan yang dilaksanakan sesuai dengan fungsi menejemn meliputi perencanaan pengorganisasian, pelaksanaan dan evaluasi. Perencanaan yang terlaksana dengan menetapkan visi, misi, dan tujuan program Gerakan Literasi Madrasah. Pengorganisasian yang memberi tanggung dan pembagian tugas pada penanggung jawab, pelakasanaan yang dilakukan sesuai dengan apa yang telah direncanakan, dan evaluasi yang mana mengkontrol semua aktivitas yang terlaksana. Dan dalam penelitian ini juga menjelaskan tentang kelebihan dan kekurangan dalam Program Gerakan Literasi Madrasah di MAN 1 Lamongan.
\end{abstract}

Keywords: Manajemen, Program Literasi 


\section{Pemdahuluan}

Peningkatan mutu pendidikan mulai dari tingkat sekolah dasar sampai sekolah menengah umumnya telah mempunyai kebijakan. Kebijakan yang telah dibuat oleh pemerintah sebaiknya diwujudkan sebaik-baiknya oleh penyelenggara (sekolah). Upaya yang dapat dilakukan untuk meningkatkan mutu pendidikan sebagai mana tercantum dalam UU No 20 Tahun 2003 tentang Sistem Pendidikan Nasional, bahwa setiap pendidikan jalur sekolah baik yang diselenggarakan oleh pemerintah maupun masyarakat harus menyediakan sumber belajar, baik dalam hal sarana maupun prasarana.1

Salah satu sarana yang dapat menunjang proses belajar dan mengajar di sekolah adalah perpustakaan. Ruang Perpustakaan merupakan salah satu prasarana yang harus dimiliki oleh lembaga pendidikan. Perpustakaan yang ada di sekolah tidak hanya berfungsi sebagai penyedia bacaan siswa di kala senggang, namun perpustakaan harus menjadi sumber, alat dan sarana untuk belajar. Artinya, penyelenggaraan perpustakaan sekolah harus sejalan dengan visi dan misi sekolah dengan mengadakan bahan bacaan yang bermutu sesuai kurikulum, menyelenggarakan kegiatan yang berkaitan dengan bidang studi, dan kegiatan penunjang lainnya. Perpustakaan harus siap setiap saat untuk menunjang dan terlibat dalam pelaksanaan proses pembelajaran, baik di dalam jam pelajaran maupun di luar jam pelajaran. Dengan kata lain perpustakaan harus membuat kegiatan ataupun program dalam rangka meningkatkan budaya literasi.2

Karena rendahnya pemahaman warga madrasah tentang manfaat gerakan literasi sesuai dengan Peraturan Menteri Pendidikan dan Kebudayaan Nomor 23 Tahun 2015 tentang Penumbuhan Budi Pekerti.3 Salah satu hal pokok yang tertuang dalam peraturan tersebut yaitu kewajiban membaca buku nonteks pelajaran selama 15 menit sebelum jam pembelajaran dimulai setiap

\footnotetext{
${ }^{1}$ Undang-Undang No. 20 Tahun 2003 tentang Sistem Pendidikan

2 Fatimah Zuhrah," Perpustakaan Sebagai Pusat Studi Islam" Jurnal Iqra' 02, No. 02 (2008)

${ }^{3}$ Peraturan Menteri Pendidikan dan Kebudayaan No. 23 Tahun 2015
} 
hari di sekolah. Berdasarkan amanat itu, Direktorat Jenderal Pendidikan Dasar dan Menengah (Ditjen Dikdasmen) meluncurkan program Gerakan Literasi Sekolah (GLS). Gerakan ini bertujuan agar siswa memiliki budaya membaca dan menulis sehingga tercipta pembelajar sepanjang hayat. Selain itu rendahnya motivasi membaca di kalangan peserta didik menjadi masalah yang memprihatikan karena di era teknologi informasi, peserta didik dituntut untuk memiliki kemampuan membaca dalam pengertian memahami teks secara analitis, kritis dan reflektif. Peserta didik belum terbiasa melakukan sesuatu berdasarkan pemahaman dari membaca dan belum dapat mengaktualisasikan diri melalui tulisan. Membaca dan menulis belum menjadi budaya dan tradisi. Mereka lebih familiar dengan media visual (menonton), verbal (lisan) atau mendengar dibandingkan membaca, apalagi menulis.

Kemampuan dalam mengakses, memahami dan menggunakan informasi secara cerdas kurang maksimal, sehingga waktu yang tersedia untuk kegiatan gerakan literasi madrasah belum sesuai dengan tujuan yang diharapkan. Oleh karena itu perlu adanya gerakan yang tepat untuk mengajak warga madrasah agar sadar akan huruf, sadar akan teknologi informasi dan sadar akan media dengan kegiatan Gerakan Literasi Madrasah ( Gelem ). Melalui Gerakan Literasi Madrasah ( Gelem ) diharapkan warga madrasah bisa mengetahui secara luas pikiran dan perasaan, mempunyai kemampuan secara baik untuk menyampaikan gagasan-gagasannya secara lisan dan tulis, Mengakses, menganalisis, mengevaluasi, dan mengkomunikasikan isi pesan yang dibaca serta mampu menghasilkan karya yang kreatif dan inovatif.

Dengan adanya program tersebut, maka madrasah sangat perlu mengetahui dan menerapkan fungsi menejemen untuk mengelola perpustakaan dan programnya. Didalam fungsi menejemen terdapat empat fungsi, yaitu perencanaan, perngorganisasian, aktualisasi, dan kontroling. Dengan memanfaatkan fungsi menejemen, madrasah dapat mempermudah menjalankan segala program literasi yang ingin dikembangkan. Mampu mencapai tujuannya yang telah direncanakan juga. Dan madrasah pun dapat meminimalisir segala kendala dan kekurangan saat berjalannya 
ataupun proses terlaksananya program Gerakan Literasi Madrasah di MAN 1 Lamongan. Berdasarkan latar belakang tersebut, maka penelitian ini akan dilaksanakan dengan judul, "implementasi Manajerial Program Gerakan Literasi Madrasah di Madrasah Aliyah Negeri 1 Lamongan".

\section{Metodologi}

Penelitian ini dilakukan di Madrasah Aliyah Negeri 1 Lamongan, jenis penelitian ini adalah penelitian kualitatif. Menurut Moleong (2007:6) penelitian kualitatif adalah penelitian yang memahami fenomena tentang apa yang dialami oleh subjek penelitian, misalnya perilaku, persepsi, motivasi, tindakan, secara holistik dan dengan cara deskripsi dalam bentuk kata-kata dan bahasa.4 Menurut Sudarto $(1997,62)$ penelitian kualitatif adalah prosedur penilaian yang menghasilkan data deskriptif berupa kata tertulis atau lisan dari orang dan perilaku yang dapat diamati.5 Pada suatu konteks khusus yang alamiah dengan memanfaatkan berbagai metode alamiah. Desain penelitian ini menggunakan penelitian studi kasus. Berdasarkan hal tersebut penelitian dapat menganalisis data secara mendalam. Adapun data yang diperoleh meliputi, bagaimana implementasi menejemen program Gerakan Literasi Madrasah di Madrasah Aliyah Negeri 1 Lamongan.

Teknik pengumpulan data yang dilakukan dalam penelitian ini menggunakan 1) Metode wawancara dilakukan kepada beberapa sumber seperti kepala madrasah, guru, petugas perpustakaan, dan siswa. 2) Metode observasi dengan mengamati keadaan fisik perpustakaan, pelayanan, dan pelaksanaan program. 3) Metode dokumen digunakan untuk mengumpulkan data arsip dan administrasi perpustakaan sekolah. Keabsahan data penelitian menggunakan triangulasi sumber dan teknik, kebsahan data tersebut digunakan untuk menguji data-data yang terkumpul.

\footnotetext{
${ }^{4}$ Moleong Lexy J, Metode Penelitian Kualitatif (Bandung : Remaja Rosdakarya, 2007), 6

${ }^{5}$ Kasiram, Metodologi Penelitian Kualitatif-Kuantitatif, (Yogyakarta :2010), 175
} 
Teknik analis data menurut Miles and Huberman mengemukakan bahwa aktivitas dalam analisis data kualitatif dilakukan secara interaktif dan berlangsung secara terus-menerus sampai tuntas, sehingga datanya penuh. Aktivitas dalam analisis ini menggunakan model interaktif yang terdiri dari pengumpulan data (data collection), pengajuan data (data display), reduksi dara (data reduction), kesimpulan (verification). 6

\section{Hasil dan Pembahasan}

Literasi berasal dari kaa bahasa latin littera yang diartikan sebagai penguasaan sistem-sistem tulisa konvensi-konvensi yang menyertainya. Selanjutnya istilah literasi lebih diartikan sebagai kemampuan baca tulis, kemudian berkembang meliputi proses membaca, menulis, berbicara, mendengar, membayangkan, dan melihat. Berkenaan dengan hal tersebut Richard Kern mendefinisikan istilah literasi, sebagai berikut:

"Literacy is the use of socially and historically and culturally situated practices of creating and interpreting meaning trough text. It entails at least a tacit awereness of the relationships between textual conventions and their context of use and, edeally, the ability to reflect critically on those relationship. Because it is purposesensitive, literacy is dinamic-non static-and variable across and within discourse communitities and cultures. It drawn on a wide range of cognitive abilities, on knowlegde of written and spoken language, on knowledge of genres, and on cultural knowledge."

Artinya, literasi adalah penggunaan praktik-praktik situasi sosial, dan historis, serta kultural dalam meciptakan dan menginterprestasikan makna melalui teks. Literasi memerlukan setidaknya sebuah kepekaan yang tak terucap tentang hubunganhubungan antara konvensi-konvensi tekstual dan konteks penggunaannya serta idealnya kemampuan untuk berefleksi secara kritis tentang hubungan-hubungan tersebut. Karena peka dengan tujuan, literasi itu bersifat dinamis-tidak statis-dan dapat bervariasi diantara dan di dalam komunitas dan kultur wacana. Literasi

${ }^{6}$ Sugiyono, Memahami Penelitian Kualitatif, (Bandung : CV. Alfabeta, 2015), 337 
memerlukan serangkaian kamampuan kognitif, pengetahuan bahasa tulisan dan lisan, pengetahuan tentang genre (pengetahuan tentang jenis-jenis teks yang berlaku dalam komunitas wacana, misalnya teks naratif, eksposisi, deskripsi, dan lain sebagainya), dan pengetahuan kultural.7

Berdasarkan pernyataan di atas dapat diketahui bahwa literasi memerlukan penguasaan kemampuan yang kompleks. Menurut Richard Kern terdapat tujuh unsur yang membentuk definisi literasi yang selanjutnya membentuk tujuh prinsip pendidikan literasi, yakni :.

1. Inteprestasi

Penulis atau pembicara dan pembaca atau pendengar berpartisipasi dalam inteprestasi, yakni penulis atau pembicara menginteprestasikan dunia (peristiwa, pengalaman, gagasan, perasaan, ide, dan lain-lain), dan pembaca atau pendengar kemudian menginteprestasi inteprestadi penulis atau pembaca dalam bentuk konsepdinya sendiri tentang dunia.

2. Kolaborasi

Terdapat kerjasama anatara dua pihak yakni penulis atau pembicara dan pembaca atau pendengar. Kerjasama yang dimaksud tersebut dalam upaya mencapai suatu pemahaman bersama. Penulis atau pembaca memutuskan apa yang harus dituliskan atau dikatakan atau yang tidak perlu ditulis aau dikatakan berdasarkan pemahaman mereka terhadap pembaca atau pendenngar. Sedangkan pembaca atau pendengar mencurahkan motivasi, pengetahuan, dan pengalaman mereka untuk memaknai teks atau pembicara.

3. Konvensi

Konvensi mencakup aturan-aturan bahasa baik lisan maupun tertulis. Seseorang membaca dan menulis atau menyimak dan berbicara ditentukan oleh konvensi atau kesepakatan kultural (tidak universal) yang berkembang melalui penggunaan dan memodifikasi untuk tujuan-tujuan individual.

4. Pengetahuan Kultural

\footnotetext{
${ }^{7}$ Ricahard Kern, Literacy and Language Teaching, (Oxport : Oxport University, 2000), 16
} 
Membaca dan menulis atau menyimak dan berbicara berfungsi dalam sistem-sistem sikap, keyakinan, kebiasaan, cita-cita, dan nilai tertentu. Untuk itu, literasi melibatkan pengetahuan kultural.

5. Pemecahan masalah

Kata-kata selalu melekat pada konteks linguistik dan situasi yang melingkupinya, maka tindak membaca, menulis, menyimak, dan berbicara melibatkan upaya membayangkan hubungan-hubungan diantara kata-kata, frase-frase, kalimatkalimat, unit-unit makna, teks-teks, dan dunia. Upaya membayangkan ini merupakan suatu bentuk pemecahan masalah.

6. Refleksi dan Refleksi Diri

Penulis atau pembaca dan pebaca atau pendengar memikirkan bahasa dan hubungan-hubungannya dengan dunia dan diri sendiri. Setelah berada dalam situasi komunikasi mereka memkirkan apa yang telah mereka katakan, bagaimana mengatakannya, dan mengapa mengatakan hal tersebut.

7. Pengguna Bahasa

Literasi bukanlah sebatas pada sistem-sistem bahasa (lisan atau tulis) melainkan mensyaratkan pengetahuan tentang bahasa tersebut digunakan baik dalam konteks lisan maupun tertulis untuk menciptakan sebuah wacana.

Dapat disimpulkan lietrasi bukanlah sebatas pada sistem-sistem bahasa (lisan atau tulis) melainkan mensyaratkan pengetahuan tentang bahasa tersebut digunakan baik dalam konteks lisan maupun tertulis untuk menciptakan sebuah wacana. ${ }^{8}$

Di Madrasah Aliyah Negeri 1 Lamongan ini memiliki program literasi yang dinamakan Gerakan Literasi Madrasah ( Gelem), yang mana program ini merupakan program intervensi pembudayaan literasi yang tepat, mudah dilaksanakan, dilakukan secara sistemik, komprehensif, merata pada semua komponen madrasah, berkelanjutan, dan dikelola secara profesional oleh lembaga yang kredibel.

\footnotetext{
${ }^{8}$ Richard Kern, Literacyand Lenguad, 16-17
} 
Membaca-menulis-mendengar-berbicara (literasi) merupakan salah satu aktivitas penting dalam hidup. Sebagian besar proses pendidikan bergantung pada kemampuan dan kesadaran literasi. Budaya literasi yang tertanam dalam diri pemustaka mempengaruhi tingkat keberhasilan baik di madrasah maupun dalam kehidupan bermasyarakat. Dan karena rendahnya budaya literasi dianggap belum sebagai masalah yang mendesak bagi warga madrasah, sehingga tidak muncul respon yang cepat, yang diperlukan, dan menjadi hal yang cenderung disepelekan oleh warga madrasah.

Madrasah ini memiliki perputakaan yang dinamakan Perpustakan Darul Fikri Madrasah Aliyah Negeri 1 Lamongan. Karena rendahnya budaya liter asi di madrasah, maka madrasah dan perpustakaan membuat ataupun mengadakan program Gerakan Literasi Madrasah (Gelem atau GLM), dan didalam program ini terdapat program gerakan literasi dengan istilah "Jambu Batu Sikat Petang" yang merupakan akronim dari pinjam buku, baca-tulis, prestasi meningkat, dan petik bintang. Adapun tujuan dari program tersebut adalah agar pemustaka aktif meminjam buku kemudian membaca dan menuliskan ide pokok atau intisarinya yang dilaksanakan setiap hari untuk meningkatkan prestasi yang unggul, sehingga memetik bintang keberhasilan sesuai harapan yang dicita-citakan. Dan mampu melatih pemustaka untuk berkarya dalam bidang tulis menulis. Sasaran dari program ini adalah seluruh siswa-siswi Madrasah Aliyah Negeri 1 Lamongan, mulai dari kelas X, XI, dan XII. Namun, tidak bisa kita pungkiri adanya kendala pada suatu hal. Seperti halnya program ini, terdapat suatu permasalahan ataupun persoalan yaitu masih saja banyak siswa siswi yang belum melaksnakan program ini, masih saja ada siswa-siswi yang tidak membaca ataupun tidak menulis ide pokok pada buku yang telah disediakan oleh madrasah. Dengan adanya kekurangan atau kendala di dalam program ini, maka madrasah membutuhkan menejemen yang mana madrasah menerapkan fungsi-fungsi menejemen.

Tertengarai dari berbagai rujukan bahwa menejemen adalah istilah yang bermakna suatu kegiatan yang mengumpulkan 
manusia untuk mencapai suatu tujuan tertentu. Menejemen mencakup kegiatan perencanaan, pengorganisasian, penyumberdayaan (resourcing), memimpin (leading) atau penentu arah (directing), dan pengendalian (controlling) sebuah organisasi atau upaya untuk meraih suatu sasaran. Sebuah organisasi terdiri dari kumpulan-kumpulan manusia atau kumpulan organisasiorganisasi. Penyumberdayaan (resourcing) adalah kegiatan peroleh atau pengumpulan dan manipulasi Sumber Daya manusia, Sumber Daya Keuangan, Sumber Daya Teknologi, dan Sumber Daya Alam. Manejemen adalah istilah yang bermakna manusia atau kumpulan manusia yang melakukan kegiatan manjemen, yang terpisah dari pekerja (labor) sebagai Sumber Daya Manusia yang dikelola menajemen.

Manajemen menurut bahasa berasal dari bahasa itali "maneggiare", bermakna mengendalikan khususnya mengendalikan kuda. Yang berasal dari bahasa latin "manus" bermakna tangan (hand). Prancis menggunakan kosa kata masnagement lalu jadi management, berpengaruh pada pembentukan kosakata inggris management pada abad 17 dan 19 (Marry Parker Follet, 1868-1933). ${ }^{9}$ Manajemen menurut istilah merupakan ilmu dan seni dalam mengelola dan mengatur sumber daya di organisasi untuk mencapai tujuan tertentu secara efektif dan efisien (Henry fayol, 1841-1925). ${ }^{10}$

Berikut adalah tahapan madrasah dalam mengembangkan program Gerakan Literasi Madrasah yang sesuai ataupun menerapkan fungsi menajemen :

1. Perencanaan (planning)

Menentukan apa yang harus terjadi dimasa depan, pembentukan rencana kegiatan. Pemimpin program ini melakukan koordinasi untuk menyusun rancangan rencana berupa bentuk kegiatan program, target program, dan berbagai hal yang terkait dengan kegiatan program yg dilakukan. Gerakan Literasi Madrasah (Gelam) diorganisasikan dengan

\footnotetext{
${ }^{9}$ Jan Hoesada, Taksonomi Ilmu Manajemen" (Yogyakarta : Penerbit ANDI, 2013), 51

10 Jan Hoesada, Taksonom, 51
} 
susunan Tim disertai tugas pokok fungsi dan wewenang yang terdiri atas Kepala madrasah, wakil kepala madrasah (bagian sarana, kurikulum, kesiswaan,humas, dan kepala penjamin mutu) kepala perpustakaan, dan guru bahasa/guru yang tertarik dengan literasi. Peran Tim dalam kegiatan ini adalah mengkoordinasikan kegiatan pengembangan literasi madrasah bekerjasama dengan guru kelas, wali kelas , BK, orang tua dan komite untuk menyusun rencana kegiatan dan dana kebutuhan ke dalam RKTM ( Rencana Kerja Tahunan Madrasah ). Setelah tim terbentuk, maka tahap kedua adalah menyusun program kerja yang berisi sasaran mutu, sasaran program, indikator keberkhasilan, kegiatan, tantangan, peluang , anggaran, penanggung jawab dan jadwal kegiatan untuk dijadikan pedoman dalam melaksanakan kegiatan literasi.

2. Persiapan

Membuat terjadi penggunaan optimal sumber daya untuk mencapai sasaran. Untuk menunjang keberhasilan kegiatan Gerakan Literasi Madrasah (Gelem), maka perlu disiapkan sarana prasarana yang mendukung antara lain keberadaan sudut baca kelas yang berisi koleksi buku nonpelajaran,(novel,kumpulan cerpen, buku ilmiah populer, kamus, komik, majalah, surat kabar, grafik, atlas, slogan membaca, poster tentang pembiasaan hidup bersih, sehat, dan indah yang disiapkan di setiap sudut kelas dengan mendesain sedemiakian rupa sehingga pembaca merasa nyaman dan enggan berpisah, bahkan selalu rindu dengan kegiatan literasi. Kegiatan ini dapat dilaksanakan dengan mengadakan lomba desain sudut baca atau perpustakaan mini, sehingga para peserta didik berlomba-lomba menghias dan mendesain pojok baca dengan giat dan senang hati. Bahan literasi bisa disiapkan melalui kegiatan tukar menukar buku pribadi, pinjam perpustakaan, sumbangan wali murid, penerbit, alumni, atau semua siswa dan warga madrasah wajib membawa satu buku Satu Orang Satu Buku yang diakronimkan dengan Sarang Sabu atau bisa juga dengan literasi murah meriah ( Murmer) dengan 
Pinjam Buku Baca Tulis Prestasi Meningkat Petik Bintang ( Jambu Batu Sikat Petang ).

Tim Literasi Gerakan Madrasah ( Gelem ) dalam melaksanakan tupoksinya agar lebih maksimal dan profesional , maka perlu belajar atau mengadakan studi tiru ke lembaga atau madrasah yang sudah melaksanakan kegiatan literasi agar mengetahui teknik dan cara mengelola kegiatan literasi sampai menciptakan produk yang bisa meningkatkan motivasi gemar berliterasi warga madrasah.

Gerakan Literasi Madrasah ( Gelem ) akan berjalan dengan baik, jika warga madrasah mendukung secara menyeluruh dan konsisten. Untuk itu perlu adanya komitmen antara kepala madrasah, Tim, guru, siswa dan warga madrasah. Selain komitmen yang dibangun, maka Sumber daya Manusia (SDM) Tim juga harus dibangun dengan mengikuti workshop literasi, selanjutnya TIM melaksanakan sosialisasi tentang pentingnya Gerakan Literasi Madrasah (Gelem) kepada warga madrasah secara berkala.

3. Pelaksanaan

Kegiatan pembiasaan wajib dilaksanakan setiap hari di kelas pada awal pembelajaran dengan membaca Al-Quran dan doa secara berjamaah yang dipandu oleh seorang siswa menggunakan audio terpusat, sedangkan peserta didik yang lain mengikuti bacaan nyaring di kelas masing-masing selama \pm 5 menit dan pada akhir pembelajaran membaca Asmaul Husna dan Doa penutup pembelajaran \pm 3 menit.

Kegiatan Literasi Madrasah ( Gelem ) dilaksanakan selama 15 menit setiap hari yang bisa dijadwalkan waktu khusus untuk membaca di awal, tengah atau akhir pelajaran, tergantung pada 
jadwal dan kondisi dan kesepakatan warga madrasah masingmasing.

Adapun bahan literasi yang dibaca adalah buku nonpelajaran, media cetak misalnya membaca berita atau media elektronik misalnya buku elektronik, atau literasi visual, misalnya membaca film pendek sesuai dengan pilihan peserta didik.

4. Tahap Pembiasaan

Kegiatan ini bisa dilaksanakan selama 15 menit membaca dengan cara guru membacakan teks dengan suara nyaring kemudian mendiskusikannya atau peserta didik membaca dalam hati yang dapat diikuti oleh diskusi informal buku yang dibaca dengan tanggapan dari peserta didik bersifat opsional. Kegiatan ini tidak diikuti oleh tugas-tugas yang bersifat tagihan /penilaian agar siswa merasa nyaman, santai dan menyenangkan. Ketika peserta didik membaca sebagai pendidik juga ikut membaca dengan tujuan untuk memotivasi peserta didik agar mau dan terbiasa membaca.

Pengukuran ketercapaian Gerakan Literasi Madrasah ( Gelem ) tahap pembiasaan bisa diukur dan dikatakan siap untuk masuk tahap berikutnya, jika telah melakukan pembiasaan 15 menit membaca ( membacakan nyaring dan membaca dalam hati) dalam kurun waktu tertentu ( satu semester ) d engan bukti peserta didik memiliki jurnal membaca harian, ada sudut baca di kelas, warga madrasah menjadi model dalam kegiatan literasi dengan ikut serta membaca 15 menit selama kegiatan berlangsung, madrasah berupaya melibatkan orang tua dan alumni untuk mengembangkan kegiatan literasi madrasah, serta kepala madrasah dan jajarannya berkomitmen melaksanakan dan mendukung gerakan literasi madrasah.

5. Tahap Pengembangan

Pada tahap pengembangan ini pelaksanaannya berlangsung selama 15 menit diawali dengan peserta didik membaca dalam hati, atau membacakan teks dengan suara nyaring yang diikuti oleh kegiatan tindak lanjut yang bertujuan untuk mengasah kemampuan peserta didik dalam menanggapi buku pengayaan secara lisan dan tulisan. Kegiatan ini memotivasi peserta didik 
untuk menunjukkan keterlibatan berpikir kritis dan analitis, kreatif dan novatif dalam menaggapi bacaan melalui kegiatan produktif baik secara lisan maupun tulisan. Perlu dipahami bahwa kegiatan produktif ini tidak dinilai secara akademik, namun bisa diberikan penghargaan bagi peserta didik yang aktif dan produktif.

Setelah peserta didik memahami bacaan, bisa dilanjutkan dengan kegiatan tugas-tugas presentasi singkat, menulis sederhana, seni peran, menanggapi bacaan, bedah buku sederhana, yang disesuaikan dengan jenjang kemampuan peserta didik. Tugas tersebut dapat dinilai secara nonakademik dengan fokus pada sikap. Namun hasil kegiatan ini bisa menjadi nilai akademik, jika tugas-tugas yang sama sesuai dengan pembelajaran.

Untuk menunjang kegiatan literasi 15 membaca dan tindak lanjut di tahap pengembangan, madrasah perlu menyusun strategi yang bisa memberikan motivasi kepada peserta didik yang telah melaksanakan kegiatan literasi dengan menyelesaiakan tugas membaca buku dan telah menuntaskan tagihan sederhana dengan cara menentukan peserta didik terbaik untuk dijadikan durta literasi tiap tahap.

Pengukuran ketercapaian kegiatan tahap pengembangan dikatakan siap untuk melanjutkan tahap berikutnya, jika telah melaksanakan kegiatan literasi selama 15 menit membaca diikuti dengan tindak lanjut menghasilkan tanggapan baik lisan maupun tulisan, memiliki portofolio yang berisi jurnal tanggapan membaca yang dipajang di kelas, ada penghargaan terhadap pencapaian kegiatan secara berkala, ada kegiatan yang mendukung wisata ke perpustakan, ada kegiata perayaan harihari tertentu bertema literasi, ada ada sudut baca di kelas, warga madrasah menjadi model dalam kegiatan literasi dengan ikut serta membaca 15 menit selama kegiatan berlangsung, madrasah berupaya melibatkan orang tua dan alumni untuk mengembangkan kegiatan literasi madrasah, serta kepala madrasah dan jajarannya berkomitmen melaksanakan dan mendukung gerakan literasi madrasah. 
6. Tahap Pembelajaran

Tahap pembelajaran ini dilakukan untuk mendukung pelaksanaan kurikulum 2013 yang mensyaratkan penyusunan rencana pelaksanaan pembelajaran semua mata pelajaran untuk memasukkan kegiatan literasi. Adapun pelaksanaan tahap ini selama 15 menit dengan melanjutkan kegiatan tahap pengembangan dan dinilai secara akademik. Kegiatan ini bertujuan untuk mengembangkan kemampuan memahami teks dan mengaitkannya dengan kehidupan sehari-hari sehingga terbentuk pribadi pembelajar sepanjang hayat, berpikir kritis , kreatif dan inovatisf serta mampu memproduksi hasil karya baik fiksi maupun nonfiksi.

Kegiatan ini berlangsung selama 15 menit diawali dengan peserta didik membaca dalam hati, membacakan teks dengan suara nyaring, atau membaca bersama dengan bahan literasi berupa buku tentang ilmu pengetahuan, kegemaran, atau bukuyang berkaitan dengan mata pelajaran tertentu. Bahan literasi juga bisa berupa grafik, cetak, visual, auditori, atau digital untuk memperkaya pengetahuan dalam mata pelajaran.

Setelah memahami bacaan peserta didik melakukan kegiatan pengembangan berupa tindak lanjut dalam bentuk menghasilkan tanggapan secara lisan maupun tulisan yang digunakan sebagai penilaian akademik. Untuk memperkaya pengetahuan dalam mata pelajaran, maka peserta didik dapat menggunakan lingkungan fisik, sosial, afektif dan akademikdisertai beragam bacaan.

Hasil tagihan akademik dipajang di kelas berupa jurnal tanggapan peserta didik, ide pokok, analisis buku, resensi, artikel atau tugas yang lain dari hasil membaca buku bacaan dan buku teks pelajaran. Peserta didik yang memiliki tagihan akademik terbaik akan mendapatkan penghargaan.

Pengukuran ketercapaian kegiatan tahap pembelajaran dapat ditentukan dengan melihat hasil kegiatan yang meliputi semua warga madrasah aktif melaksanakan kegiatan literasi selama 15 menit. Ada pengembangan berbagai strategi membaca untuk memahami teks dalam semua mata pelajaran yang diikuti 
dengan tagihan akademik kepada peserta didik. Ada berbagai kegiatan tindak lanjut dalam bentuk menghasilkan tanggapan atau hasil karya, baik dalam bentuk lisan maupun tulisan yang dipajang di kelas serta mengadakan unjuk karya. madrasah berupaya melibatkan orang tua dan alumni untuk mengembangkan kegiatan literasi madrasah, serta kepala madrasah dan jajarannya berkomitmen melaksanakan dan mendukung gerakan literasi madrasah. Tidak kalah pentingnya peranan perpustakaan dalam pengadaan bahan literasi baik fiksi maupun nonfiksi untuk menambah wawasan peserta didik dalam mengembangkan ilmu pengetahuan mata pelajaran tertentu.

7. Tahap Pelaporan

Untuk meningkatkan mutu pengembangan program Gerakan Literasi Madrasah ( Gelem ), maka Tim literasi madrasah menyusun lapoan hasil kegiatan untuk mengetahui kelebihan dan kelemahan serta tindak lanjut program kegiatan yang akan datang.

8. Evaluasi

Pelaksanaan monitoring dan evaluasi dilakukan sekali dalam satu tahun secara berjenjang oleh pemangku kepentingan mulai dari kepala madrasah, pengawas, kemenag kabupaten, kemenag kanwil sampai kemenag pusat. Untuk mengetahui ketercapaian Gerakan Literasi Madrasah ( Gelem ), monitoring dan evaluasi dapat dilaksanakan dengan mengadakan lomba literasi tingkat satuan pendidikan, tingkat Kelompok Kerja Madrasah ( KKM ), tingkat Wilayah Kerja Madrasah ( Wilker ), tingkat provinsi sampai tingkat pusat.

Melaksanakan penilaian hasil kegiatan literasi sebagai berikut :

a. Setiap akhir bulan guru bahasa memberikan penghargaan nilai ( A.B.C.D dan E ) dan menandatangani buku laporan kegiatan literasi dan melaporkan prosentase pelaku literasi kepada petugas perpustakaan sebagai bukti kunjungan perpustakaan kelas/sudut baca. 
b. Setiap akhir bulan wali kelas menandatangani laporan kegiatan literasi dan memberikan motivasi untuk meningkatkan kegemaran dalam berliterasi.

c. Hasil Penilaian lomba literasi dan sudut baca diumumkan pada saat upacara baik berdasarkan kelas maupun individu.

d. Pada akhir semester Bapak/Ibu guru yang melaksanakan literasi tahap pembelajaran bisa menagih tugas literasinya dan hasilnya bisa dibukukan atau dijilid kemudian disimpan di perpustakaan induk (misalnya antologi, hasil analisis, resensi, kamus dan hasil karya yang lain).

e. Nilai penghargaan dalam buku laporan literasi "Jambu Batu Sikat Petang." Bisa digunakan untuk menambah nilai hasil pembelajaran siswa.

f. Pada akhir semester, hasil kegiatan literasi madrasah diwujudkan dalam bentuk karya tulis bisa berupa puisi, cerpen, atau artikel dan karya yang lain.

9. Pelaporan

a. Pada akhir tahun pembelajaran, siswa menyerahkan buku laporan hasil kegiatan literasi ke perpustakaan untuk mendapatkan surat keterangan telah melaksanakan gerakan literasi madrasah yang digunakan sebagai persyaratan pengambilan raport .

b. Hasil karya kegiatan gerakan literasi siswa dipilih dan dibukukan dalam bentuk antologi. Dapat kita simpulkan, bahwa Madrasah Aliyah Negeri 1 Lamongan ini telah memiliki niat dan program kegiatan yang sangat menunjang dalam meningkatkan budaya literasi di Madrasah Aliyah Negeri 1 lamongan ini, dengan program Gerakan Literasi Madrasah dan didalam program tersebut juga memiliki banyak kegiatan-kegiatan untuk berliterasi. Dan dalam menjalankan program tersebut, madrasah dan perpustakaan yang berkolaborasi untuk mengelola program tersebut, menggunakan teori-teori manajemen yang ada, dan diterapkan dalam pelaksanaannya. Sehingga program 
tersebut dapat berjalan dengan lancar, dan mampu mencapai tujuan yang telah disepakati.

\section{Kelebihan Dan Kekurangan}

Dalam program ini, terdapat beberapa kekurangan dan kelebihan. Yang mana kekurangannya adalah : Tidak semua peserta didik melakukan ataupun melaksanakan program ini, sehingga sasaran yang dituju belom secara keseluruhan. Namun, dilain sisi didalam program ini terdapat banyak kelebihan yang berdampak pada peserta didik, berikut adalah kelebihan program Gerakan Literasi : 1) Dapat meningkatkan pengetahuan ataupun wawasan peserta didik, 2) Mampu meningkatkan budaya membaca peserta didik, 3) Dan mampu melatih peserta didik dalam berkarya dalam bidang tulis-menulis, dan lain sebagainya.

\section{References}

\section{Books and Articles}

Fatimah, Zuhrah,"Perpustakaan Sebagai Pusat Studi Islam" Jurnal Iqra' 02, No. 02 (2008)

Hoesada, Jan, Taksonomi Ilmu Manajemen" (Yogyakarta : Penerbit ANDI, 2013)

Kasiram, Metodologi Penelitian Kualitatif-Kuantitatif, (Yogyakarta :2010)

Kern, Ricahard, Literacy and Language Teaching, (Oxport : Oxport University, 2000)

Lexy, J Moleong, Metode Penelitian Kualitatif (Bandung : Remaja Rosdakarya, 2007)

Peraturan Menteri Pendidikan dan Kebudayaan No. 23 Tahun 2015

Sugiyono, Memahami Penelitian Kualitatif, (Bandung : CV. Alfabeta, 2015)

Undang-Undang No. 20 Tahun 2003 tentang Sistem Pendidikan 